\title{
A New Type of Transition from Stem to Root in the Vascular System of Seedlings.
}

BY

\author{
ETHEL SARGANT. \\ $\rightarrow+$ \\ With Plate XXXIII.
}

FOR some years I have been studying the comparative
anatomy of Monocotyledonous seedlings, and I have paid particular attention to the transitional region in which the vascular system of the stem assumes the characters of a root-stele. This subject is the more interesting, as the anatomy of that region has as yet been described in few species of Monocotyledons. M. Gérard ${ }^{1}$ describes it in nine Monocotyledons, and states expressly that his choice of material was limited because he was obliged to pick out species with comparatively long transitional regions. This is unavoidable when hand-sections only are prepared; with the microtome very few seedlings are unmanageable.

In the Wild Hyacinth (Scilla festalis, Salisb., Endymion or Agraphis of some authors), for instance, the transitional region is not only short but its symmetry is confused by the early formation of a vascular girdle from which the first cauline roots are given off. I have found it impossible to trace the behaviour of each stem-bundle during the transition with complete certainty in this species, although I have four perfect series of microtome sections cut through the critical regions of four well-grown seedlings at the right age.

Such cases, however, are exceptional, and so are those

1 Gérard, Recherches sur le passage de la racine à la tige. (Ann. des Sc. Nat., Bot., $6^{\ominus}$ sér., t. xi, $188 \mathrm{r}$.)

[Annals of Botany, Vo1. XIV. No. LVI. December, I900.] 


\section{Sargant. - A New Type of Transition from}

in which any serious difficulty of manipulation arises. As a rule it is a simple matter to make out the facts in good material at the right stage of growth.

In the second French edition of his 'Traité de Botanique,' M. Van Tieghem has described three types of transition from a stem to a root-structure in the primary axis of Angiospermous seedlings (1891, p. 782). Tracing the transition downwards from stem to root, as I am accustomed to do, these types are shortly as follows :-

I. The number of xylem and phloem-bundles in the upper part of the hypocotyl is the same as the number of such bundles in the stele of the primary root. The transition takes place by the branching of each internal xylem-group to right and left of the phloem-group external to it. The protoxylem of each branch turns outwards during the process. The phloem-groups remain in situ, and each is now divided from the next by a pair of xylem-branches with external protoxylem. Each pair fuses into a single group, and the root-stele is complete.

2. The number of xylem and phloem-groups in the upper part of the hypocotyl is twice that of the corresponding bundles in the stele of the primary root. The transition takes place by the fusion of the phloem-groups in pairs. The xylem-groups also approach each other in pairs, the protoxylem of each group becoming external during the process. Thus each pair of centrifugal xylem-groups becomes a single group of centripetal xylem.

3. The number of xylem and phloem-groups in the upper part of the hypocotyl is the same as that characteristic of the primary root-stele. The transition takes place by the branching of each phloem-group to the right and left of the xylem-group within it. At the same time the xylemgroups rearrange their elements so that those of the protoxylem become external. Thus each centripetal xylem-group is divided from the next by a pair of phloem-branches. When a new phloem-group has been constituted from each pair of branches, the root-stele is complete. 
I worked out the details of this transition in many Monocotyledonous seedlings before hitting on a case which would not fit into one of these three schemes. The young seedlings of Anemarrhena asphodeloides, however, belong to a fourth and hitherto undescribed type. In many respects it is the converse of M. Van Tieghem's second type, just as his third is the converse of his first ${ }^{1}$.

Anemarrhena asphodeloides is a herbaceous perennial belonging to the tribe Asphodelex of the order Liliaceæ. It is native to the north of China, but is occasionally cultivated in Japanese gardens (Benth. et Hook. Gen. Plant., vol. III, p. 782). Professor S. Ikeno has been good enough to send me seeds of this plant among others, from which I was able without difficulty to raise seedlings for my work. I have had no opportunity of examining the mature plant. One young specimen raised from seed is now in its second year. The root-stock is much flattened and almost disk-shaped; from it spring several shoots of very narrow grass-like leaves. This young plant has not yet flowered.

The three seedlings from which my preparations were made were eleven days old. Fig. I (Plate XXXIII) represents the largest $\left(A_{3}\right)$ and the smallest $\left(A_{1}\right)$ of the trio. The plumule in both is completely enclosed within the base of the cotyledon and is embryonic (Fig. 3). This makes it quite clear that the symmetry of the root-stele is determined by the cotyledonary traces only.

The preparations figured are all from a single seedling $\left(A_{3}\right)$, and the levels through which they are cut are shown in the outline of $A_{3}$ (Fig. I). The seed-coats have been shed from this specimen, and the tapering apex of the cotyledon is exposed. A hand-section through this region shows two massive bundles with particularly large phloem-groups, symmetrically placed within the oval outline of the section (Fig. 2). These two bundles run down the cotyledon. They are seen with the same orientation in two hand-sections, not

1 E. Sargant, On a Fourth Type of Transition from Stem to Root Structure (Report, British Assoc., Bradford, 1 900). 


\section{Sargant.-A New Type of Transition from}

figured here, taken about the level marked by a dotted line through $A_{3}$ in Fig. I. The outline of the section is still oval, but a slight groove marks the inner surface of the cotyledon.

The preparations drawn in the four following figures (3-6) are from a microtome series through the region marked by a bracket in the outline of $A_{3}$ (Fig. I). The first (Fig. 3) passes through the embryonic stem-bud enclosed in the sheath-like base of the cotyledon. Besides the two massive bundles of the cotyledon, the section shows three procambial strands in the first leaf. The section drawn in Fig. 4 is $.34 \mathrm{~m}$.m. below this. The plumular traces, still embryonic in character, are entering the stele formed by the cotyledonary traces. This marks the first node of the young axis, and the upper limit of the hypocotyl proper. The two lateral plumular traces $(B$ and $C)$ are in the act of joining the stele. The plumular midrib $A$ has divided, and its branches follow $B$ and $C$ respectively. The transition to a root-structure has already begun in the cotyledonary stele by the division of each large phloem-mass. Each cotyledonary trace has now a pair of phloem-groups, and a single wedge-shaped mass of xylem with well-marked internal protoxylem (Fig. 4).

The fusion of the plumular traces with those of the cotyledon is complete at the level of Fig. 5, which is drawn from a section cut $3 \mathrm{~m}$.m. lower than that drawn in Fig. 4 . In this section (Fig. 5) the protoxylem-group of each cotyledonary trace has divided into three parts, each of which is on the way to become external. The medium protoxylem group of each trace $\left(p x_{1}\right.$, and $\left.p x_{4}\right)$ will ultimately divide the two branches of each phloem-group from each other. That is, $p x_{1}$, when completely external, will divide $P h_{1}$ from $P h_{2}$, and $p x_{4}$ will divide $P h_{1}{ }^{\prime}$ from $P h_{2}{ }^{\prime}$. The two lateral protoxylem-groups of each trace will occupy the space intermediate between the two traces; $p x_{2}$ and $p x_{2}^{\prime}$ dividing $P h_{1}$ from $P h_{1}^{\prime}$, and $p x_{3}$ with $p x_{3}{ }^{\prime}$ dividing $P h_{2}$ from $P h_{2}{ }^{\prime}$.

This process is almost complete in the section drawn in Fig. 6, which is 35 m.m. below that drawn in Fig. 5. All 
the protoxylem-groups are external. The lateral groups $p x_{3}$ and $p x_{3}^{\prime}$ have fused with each other. The lateral groups $p x_{2}$ and $p x_{2}^{\prime}$ are on the point of fusing. The stele is already practically that of a root, and is surrounded by an endodermis (Fig. 6).

It is to be regretted that the three series of sections which have been cut through the hypocotyls of three separate seedlings have all been more or less damaged in preparation. The thin-walled tissues in all are crushed and even distorted by the embedding processes necessary before cutting with a microtome. This is least conspicuous in the series from seedlings $A_{3}$, and for this reason I have figured sections from this series, but even in this the crumpled cell-walls are unmistakable, particularly when compared with the tissues in Fig. 2, drawn from a hand-section through the same seedling. The behaviour of the xylem and phloem-bundles is, however, identical in the three seedlings examined, and the transition takes place in each with diagrammatic precision.

The characteristic feature of this transition is that two bundles only enter the hypocotyl which passes into a root with tetrarch symmetry from the beginning. In the second type described by M. Van Tieghem (1.c.) the number of phloem or xylem-bundles entering the hypocotyl from above is twice that of the corresponding bundles in the primary root. This is a common structure among Dicotyledons, as in many Crucifers, but I have not yet found it among Monocotyledons. The fourth scheme, of which Anemarrhena is the type, is the converse of this. The stem-bundles entering the hypocotyl are only half as many as those forming the primary root.

A similar structure, but much confused by the presence of plumular traces in the stele of the hypocotyl, and by various irregularities during the transition, is found in the allied genera Asphodelus and Asphodeline. 


\title{
${ }_{3} 8$ Sargant. - The Vascular System of Seedlings.
}

\section{EXPLANATION OF FIGURES IN PLATE XXXIII.}

\author{
Illustrating Miss E. Sargant's Paper on A New Type of Transition from Stem \\ to Root in the Vascular System of Seedlings.
}

Fig. I. Outlines of two of the seedlings cut $\left(A_{1}\right.$ and $\left.A_{3}\right)$. The apex of the cotyledon is still hidden within the seed in $A_{1}$. The numbered lines drawn through the outline of $A_{3}$ refer to the following figures; thus the hand-section drawn in Fig. 2 was cut about the level marked 2 in the outline drawing. Life size.

Fig. 2. Hand-section through upper part of cotyledon $\left(A_{3}\right)$, showing the two massive bundles within it. The orientation of this section does not correspond with that of the series from which Figs. 3-6 were drawn. $\times 75$.

Figs. 3-6. Four successive sections from a microtome series through the region marked 3-6 in Fig. I. The orientation is uniform in all, and the lettering as follows :-

$M, M^{\prime}$. . . . . . . . cotyledonary bundles.

A. . . . . . . . . midrib-trace of first leaf.

$P h_{1}, P h_{2} \quad$. . . . . . . branches of phloem-group belonging to bundle $M$.

$P h_{1}{ }^{\prime} P h_{2}{ }^{\prime}$. . . . . . . branches of phloem-group belonging to bundle $M^{\prime}$.

$p x_{1}, p x_{2}, p x_{3}$. . . . . . protoxylem-groups derived from bundle $M$.

$p x_{4}, p x_{1}, p x_{1}$. . . . . . protoxylem-groups derived from bundle $M^{\prime}$.

Fig. 3. Base of stem-bud, showing embryonic first leaf and growing point completely enclosed within base of cotyledon. $\times 75$.

Fig. 4. 34 m.m. below Fig. 3. Lateral traces of first leaf are fusing with $M$ and $M^{\prime}$ respectively. Midrib-trace $(A)$ is dividing and will shortly follow the lateral traces. The phloem-groups of $M$ and $M^{\prime}$ have each divided; the protoxylem-groups are as yet undivided and external. $\times 75$.

Fig. 5. 3 m.m. below Fig. 4. Central cylinder only, more highly magnified. Plumular traces have fused with cotyledonary traces. Three groups of protoxylem in each cotyledonary trace, becoming external. $\times 200$.

Fig. 6. $\cdot 35 \mathrm{~m} . \mathrm{m}$. below Fig. 5. Transition nearly over. The central cylinder is surrounded by an endodermis. Three external groups of protoxylem are in situ; the fourth is not yet complete $\left(p x_{2}, p x_{2}{ }^{\prime}\right)$. Four groups of phloem alternate with the xylem-groups. $\times 200$. 


\section{$2 \mathrm{BHL}$ Biodiversity Heritage Library}

Sargant, Ethel. 1900. "A new type of transition from stem to root in the vascular system of seedlings." Annals of botany 14, 633-638.

https://doi.org/10.1093/oxfordjournals.aob.a088796.

View This Item Online: https://www.biodiversitylibrary.org/item/238259

DOI: https://doi.org/10.1093/oxfordjournals.aob.a088796

Permalink: https://www.biodiversitylibrary.org/partpdf/318603

\section{Holding Institution}

Smithsonian Libraries

\section{Sponsored by}

Biodiversity Heritage Library

\section{Copyright \& Reuse}

Copyright Status: Not in copyright. The BHL knows of no copyright restrictions on this item.

This document was created from content at the Biodiversity Heritage Library, the world's largest open access digital library for biodiversity literature and archives. Visit BHL at https://www.biodiversitylibrary.org. 